\title{
Hepatocellular Carcinoma with Portal Vein
} Tumor Thrombus versus Hepatocellular Carcinoma with Biliary Tumor Thrombus:

\section{Better or Worse Prognoses? [Response to Letter]}

This article was published in the following Dove Press journal: Cancer Management and Research

\author{
Xin Yang $\mathbb{D}^{1, *}$ \\ Ying Zhu (D) ${ }^{1, *}$ \\ Xia Zhao ${ }^{2, *}$ \\ Jian-Hua Li $\mathbb{D}^{1, *}$ \\ $\mathrm{Da} X \mathrm{u}^{\prime}$ \\ Hu-Liang Jia' \\ Jubo Zhang ${ }^{3}$
}

'Department of General Surgery, Huashan Hospital \& Cancer Metastasis Institute, Fudan University, Shanghai, People's Republic of China; ${ }^{2} \mathrm{Health}$ Management Center, Huashan Hospital, Fudan University, Shanghai, People's Republic of China; ${ }^{3}$ Department of Infectious Diseases, Huashan Hospital, Fudan University, Shanghai, People's Republic of China

*These authors contributed equally to this work

Correspondence: Jubo Zhang

Department of Infectious Diseases, Huashan Hospital, Fudan University, 12 Urumqi Road (M), Shanghai, 200040,

People's Republic of China

Tel +86-2I-52887I 70

Email drzhangjubo@।63.com

Hu-Liang Jia

Department of General Surgery, Huashan Hospital, Cancer Metastasis Institute,

Fudan University, 12 Urumqi Road (M),

Shanghai, 200040, People's Republic of

China

Tel +86-2I-52887I75

Email jbl-I@।63.com

\section{Dear editor}

First of all, we would like to thank Professor Chen from the Eastern Hepatobiliary Hospital for his comments. Professor Chen has put forward a lot of views and references for us, which will be the direction and focus of our future work. The prevalence, clinical characteristics, and oncology results of HCC patients with PVTT and BDTT vary greatly. Therefore, it is necessary to explore the prognosis of HCC patients with different types of tumor thrombosis to guide the treatment of patients. Although we have received more patients with liver cancer combined with tumor thrombi, fewer patients are truly eligible for surgery, especially those with bile duct tumor thrombi. This is also the main reason for our small sample size. Of course, a small sample may lead to one-sided conclusions, which may only be for reference. In Table 3, because there are a large number of PVTT patients, and PVTT is habitually placed first. In fact, high-risk one (BDTT) should be placed first, and it should be BDTT verse PVTT. We are very sorry, this is a small mistake in our writing, which caused misunderstanding. According to the literature data provided by Professor Chen, the prognosis of BDTT patients does not seem to be inferior to that of PVTT patients. For a correct conclusion, it may require larger sample sizes and more retrospective studies from more centers at home and abroad. Collecting more clinical data may be more helpful for drawing correct conclusions. According to Professor Chen's suggestions, we will collect more comprehensive clinical data for research in the future. Finally, we hope that more scholars will pay attention to and conduct research on liver cancer combined with tumor thrombi to improve the prognosis of these patients.

\section{Disclosure}

The authors report no conflicts of interest in this communication. 
Dove Medical Press encourages responsible, free and frank academic debate. The content of the Cancer Management and Research 'letters to the editor' section does not necessarily represent the views of Dove Medical Press, its officers, agents, employees, related entities or the Cancer Management and Research editors. While all reasonable steps have been taken to confirm the content of each letter, Dove Medical Press accepts no liability in respect of the content of any letter, nor is it responsible for the content and accuracy of any letter to the editor.

Cancer Management and Research

Dovepress

\section{Publish your work in this journal}

Cancer Management and Research is an international, peer-reviewed open access journal focusing on cancer research and the optimal use of preventative and integrated treatment interventions to achieve improved outcomes, enhanced survival and quality of life for the cancer patient.

Submit your manuscript here: https://www.dovepress.com/cancer-management-and-research-journa
The manuscript management system is completely online and includes a very quick and fair peer-review system, which is all easy to use. Visit http://www.dovepress.com/testimonials.php to read real quotes from published authors. 